\title{
Use of objective measurement in the validation of self-reported smoking in children aged 10 and 11 years: saliva thiocyanate
}

\author{
PAMELA A GiLliES, ${ }^{1}$ BRIAN WILCOX, ${ }^{2}$ CLAIRE COATES, ${ }^{3}$ FANNEY \\ KRISTMUNDSDÖTTIR, ${ }^{4}$ AND DONALD J REID ${ }^{5}$ \\ From the Departments of Community Health, ${ }^{1}$ and Human Morphology, ${ }^{3}$ University Hospital and Medical \\ School, Nottingham, the City of Sheffield, MDC Education Department, ${ }^{2}$ Sheffield, the Department of \\ Anatomy, ${ }^{4}$ Medical School, Manchester, and the Health Education Council, ${ }^{5}$ London, UK
}

SUMMARY This study of objective measurement of smoking behaviour reports the findings from a sample of 421 children aged 10 and 11 years from Sheffield. Saliva thiocyanate determination did not provide a satisfactory objective method of validating the self-reported smoking of children in this age group. There was a trend (non-significant) for non-smoking children from homes in which a close relative smoked to have higher concentrations of saliva thiocyanate than non-smokers from "non-smoking" homes. Prior knowledge that a scientific test predicting smoking behaviour would be taken after completion of a questionnaire on smoking increased the self-reportage of experimental smoking.

Information about smoking among children has largely been gathered through self-reportage. The validity of self-reportage has been questioned on the grounds that smoking is not socially accepted behaviour among many young teenagers and would, in consequence, be likely to be under-reported. ${ }^{1}$ Evans et $a l^{2}$ have noted that "more objective measures of smoking behaviour than self-reports of smoking are vital for a valid evaluation of programmed treatments."

Many studies have reported that the concentration of thiocyanate ions $\left(\mathrm{SCN}^{-}\right)$excreted in the saliva of adults is related to smoking and to the level of cigarette consumption. ${ }^{3-8}$ The raised concentrations of thiocyanate in the saliva of adult smokers largely result from the detoxification of hydrogen cyanide gas in cigarette smoke.

Although saliva thiocyanate determination is a non-invasive technique, it has been used only recently to validate children's self-reported smoking. Hurd et $a l^{9}$ have indicated that thiocyanate concentrations in saliva corroborated self-reported smoking in children aged 12 to 13 in Minnesota. Another research team from Minnesota have reported that saliva thiocyanate concentrations in children aged 12 to 14 were related to cigarette consumption and, in addition, that prior knowledge of the existence of an objective test of smoking increased the level of self-reportage of regular smoking. ${ }^{10}$

The primary aim of the study reported here was to test the effectiveness of saliva thiocyanate determination in the validation of self-reported smoking in children aged 10 and 11 . The study also aimed to investigate the possibility that prior knowledge of a saliva test that may detect smoking might affect the level of self-reportage. Owing to the current interest in passive or "secondary" smoking, ${ }^{11-13}$ this study also reports on the saliva thiocyanate concentrations of non-smoking children in relation to information gained from self-reportage as to parental and sibling smoking behaviour in the home.

\section{Methods}

The sample consisted of 421 pupils aged 10 and 11 (boys 218, girls 203) from six primary schools in Sheffield who took part in a longitudinal study of the prevalence of smoking. ${ }^{14}$

Teachers randomly assigned their pupils to one of three groups. Group A completed a questionnaire only $(n=142$; boys 80 , girls 62$)$. Group B completed an identical questionnaire immediately before providing a saliva specimen and without prior knowledge of specimen collection $(n=138$; boys 72 , 
girls 66). Group $C$ completed the questionnaire before specimen collection but were advised in advance that specimens were to be asked for immediately after completion of the questionnaire and that these specimens would then be tested for evidence of smoking $(n=141$; boys 66 , girls 75$)$.

The purpose of a questionnaire-only group was to test, so far as possible, any effect that the provision of a saliva specimen might have on the subsequent reporting of smoking behaviour in later years.

Information was gained from a standardised questionnaire derived from an instrument used in a long-term study of smoking in Derbyshire school children. ${ }^{15}$ To obviate any potential reading difficulties the questionnaire was read through with the children by one of the researchers. The questionnaire contained closed response items on the smoking behaviour of children themselves, their parents, and siblings, and the key question regarding children's own behaviour was as follows:

Please read the following statements carefully and tick $(\sqrt{ })$ the space which best describes you (tick one space only)

\section{I have never smoked a cigarette}

I have only ever tried smoking once

I have smoked sometimes, but I don't smoke as much as one cigarette a week

I usually smoke between one and six cigarettes a week

I usually smoke more than six cigarettes a week

All 421 children from the total sample voluntarily completed a questionnaire, and $417(99 \%)$ of these were completed satisfactorily.

\section{SALIVA THIOCYANATE PROCEDURE}

Children were asked to provide a 1-2 ml specimen of saliva in plastic containers which were then sealed with airtight stoppers. Samples were frozen at $-20^{\circ} \mathrm{C}$ within six hours of collection and stored for analysis one week later.

After thawing, a 1-ml sample was removed for analysis by the colorimetric method of Densen $\mathrm{et} \mathrm{al}^{\mathbf{5}}$ and concentrations of saliva thiocyanate were determined in relation to known standards. The critical level for determining an individual who smoked was taken to be a concentration of thiocyanate $\geqslant 100 \mu \mathrm{g} / \mathrm{ml}$. This "cut-off" point was established by Hurd et al. ${ }^{9}$ The reliability of the method was tested with a $10 \%$ random sample of specimens. A total of 30 split samples were analysed with the researcher blind as to the pairs' identity.
Linear regression analysis showed the method to be highly reliable $(r=0.98)$.

Viable samples and satisfactorily completed questionnaires were analysed in the case of 264 children (94.6\% of original sample of 279). Twelve children indicated that they had eaten cyanogenic foodstuffs-for instance, cabbage, turnips-before the specimens were collected. As these foodstuffs appear to raise the concentration of thiocyanate ions in saliva,$^{16}$ the responses of this small group were analysed separately. The main body of results therefore details the findings from 252 children (boys 125 , girls 127 )-that is, $90 \%$ of the "saliva" sample.

\section{Results}

OBJECTIVE MEASUREMENT OF SMOKING BEHAVIOUR

Three of the nine self-reported smokers in the sample were found to have saliva thiocyanate concentrations $\geqslant 100 \mu \mathrm{g} / \mathrm{ml}$. A large proportion of false-positive results were recorded. False-positives refer to individuals who indicated that they did not smoke but for whom the recorded concentration of thiocyanate nevertheless exceeded the critical level of $100 \mu \mathrm{g} / \mathrm{ml}$. Of the non-smoking sample $(n=243), 45$ or $18.5 \%$ had saliva thiocyanate concentrations above the critical point for determining smokers.

Variation between individual results was great, and a wide range of thiocyanate concentrations was observed (minimum $=18 \mu \mathrm{g} / \mathrm{ml}$; maximum $=220 \mu \mathrm{g} / \mathrm{ml}$ ).

EFFECT OF PRIOR KNOWLEDGE OF SALIVA TEST ON SELF-REPORTAGE OF SMOKING

For those who smoke "regularly" (one or more cigarettes a week)

In all, only 11 children (2.64\%) from the total sample of 417 reported that they smoked on a regular basis. The reported prevalence of smoking among those children who completed a questionnaire with and without prior knowledge of saliva testing was $2 \cdot 5 \%$ $(n=7)$ and $2 \cdot 9 \%(n=4)$ respectively.

For those who had experimented with smoking (had tried smoking once, excluding the 11 regular smokers)

A total of 113 children ( $28 \%$ of sample excluding regular smokers) claimed to have experimented with smoking. The hypothesis that there was no difference in the reportage of experimentation in relation to the knowledge that a subsequent saliva test would be taken was tested using chi-square (table 1). Analysis of results for groups A and B combined (no prior knowledge of saliva test) and group C (prior 
Table 1 Incidence of experimentation by cohort group and sex (excluding regular smokers)

\begin{tabular}{|c|c|c|c|}
\hline \multirow[b]{2}{*}{ Group } & Boys & Girls & Total \\
\hline & No & $\mathrm{No}$ & No \\
\hline $\begin{array}{l}\text { Group } A \\
\text { Satisfactorily completed a } \\
\text { questionnaire only } \\
\text { (n= 138; boys } 77, \text { girls } 61 \text { ) } \\
\text { Group B }\end{array}$ & $\begin{array}{l}28 \\
(36 \%)\end{array}$ & $\begin{array}{c}7 \\
(11 \%)\end{array}$ & $\begin{array}{l}35 \\
(25 \%)\end{array}$ \\
\hline $\begin{array}{l}\text { Satisfactorily completed a } \\
\text { questionnaire and gave a } \\
\text { saliva specimen but had no } \\
\text { prior knowledge of saliva testing } \\
\text { (n = 133; boys } 69, \text { girls } 64 \text { ) } \\
\text { Group } C\end{array}$ & $\begin{array}{l}20 \\
(29 \%)\end{array}$ & $\begin{array}{l}10 \\
(16 \%)\end{array}$ & $\begin{array}{l}30 \\
(23 \%)\end{array}$ \\
\hline $\begin{array}{l}\text { Satisfactorily completed a } \\
\text { questionnaire and gave a } \\
\text { saliva specimen but did have } \\
\text { knowledge of saliva testing } \\
\text { before questionnaire completed } \\
\text { ( } n=135 \text {; boys } 62, \text { girls } 73 \text { ) }\end{array}$ & $\begin{array}{l}31 \\
(50 \%)\end{array}$ & $\begin{array}{l}17 \\
(23 \%)\end{array}$ & $\begin{array}{l}48 \\
(36 \%)\end{array}$ \\
\hline
\end{tabular}

knowledge of saliva test) for boys and girls together, indicated that there was a difference that was statistically significant $\left(\chi^{2}=5.97 ; \mathrm{df}=1 ; \mathrm{p}<0.02\right)$.

POSSIBLE EFFECT OF PARENTAL OR SIBLING SMOKING OR BOTH IN THE HOME ON THE SALIVA THIOCYANATE CONCENTRATIONS OF NON-SMOKING CHILDREN

While not quite reaching statistical significance $\left(\chi^{2}=3 \cdot 32 ; \mathrm{df}=1 ; \mathrm{p}>0.05\right)$, the results (table 2$)$ suggest that non-smokers from a home in which a close relative smoked were more likely than non-smokers from homes in which none of the close relatives smoked to have very high saliva thiocyanate concentrations - that is, levels $\geqslant 100 \mu \mathrm{g} / \mathrm{ml}$.

\section{Discussion}

SALIVA THIOCYANATE AS AN OBJECTIVE MEASURE OF SMOKING

As Hurd et $a l^{9}$ did not detail their findings quantitatively, direct comparisons with their data are unfortunately impossible. Contrary to their

Table 2 Non-smoking children with saliva thiocyanate concentrations $\geqslant 100 \mu \mathrm{g} / \mathrm{ml}$ and $<100 \mu \mathrm{g} / \mathrm{ml}$ by parental/ sibling smoking at home

\begin{tabular}{|c|c|c|c|}
\hline Category & $\begin{array}{l}\text { At least one } \\
\text { parent/sibling } \\
\text { smokes }\end{array}$ & $\begin{array}{l}\text { Parents/siblings } \\
\text { do not smoke }\end{array}$ & Total \\
\hline $\begin{array}{l}\text { Non-smokers whose saliva } \\
\text { thiocyanate was } \geqslant 100 \mu \mathrm{g} / \mathrm{ml} \\
\text { - that is, those giving false- } \\
\text { positive results }\end{array}$ & $\begin{array}{c}37 \\
(21 \%)\end{array}$ & $\begin{array}{l}8 \\
(11 \%)\end{array}$ & $\begin{array}{l}45 \\
(19 \%)\end{array}$ \\
\hline $\begin{array}{l}\text { Non-smokers whose saliva } \\
\text { thiocyanate was }<100 \mu g / m l \\
\text {-that is, those not giving } \\
\text { false-positive results }\end{array}$ & $\begin{array}{l}136 \\
(79 \%)\end{array}$ & $\begin{array}{l}62 \\
(89 \%)\end{array}$ & $\begin{array}{l}198 \\
(81 \%)\end{array}$ \\
\hline Total & 173 & 70 & 243 \\
\hline
\end{tabular}

observation, however, the results of this study indicated that at least with young children aged 10 and 11 , saliva thiocyanate determination did not provide an adequate measure in the validation of self-reported smoking. It correctly identified only three of the nine children who indicated, by questionnaire, that they were regular smokers. With one exception, the children claimed to smoke one to three cigarettes a week. The high level of false-negative results observed suggests that the test may not be particularly sensitive to the low levels of smoking that characterise this young age group. It must be borne in mind, however, that the number of children in the "smoking category" was extremely small.

The high rate of false-positive results noted in this study (18.5\% of non-smokers) and the wide ranging variability of individual results cast doubts on the specificity of the test, although Luepker et $a l^{10}$ recorded a low false-positive rate of $2.3 \%$ with children aged 12 to 14 .

EFFECT OF PRIOR KNOWLEDGE OF A BIOCHEMICAL TEST FOR SMOKING ON THE LEVEL OF SELF-REPORTED SMOKING

It has been noted that the reportage of regular smoking among children aged 12 to 14 who were made aware that they would subsequently take a saliva test was twice as high as the level recorded for a similar group who were unaware that they would take such a test. ${ }^{10}$ The results gained from this study did not support this finding in respect of regular smoking, though this may partly reflect the low prevalence of smoking among children of this age group. The level of reportage of experimental smoking (tried smoking once) was, however, significantly higher among those children in this study who were aware that they would take a saliva test than among those who were unaware of the test. This finding may be of some import in respect of research methods used in future investigations of smoking among children.

In relation to the age at which preventive smoking strategies should be introduced it is of major interest that over one-quarter of the children in this sample (excluding regular smokers) claimed to have experimented with smoking by the age of 10 to 11 years.

PARENTAL AND SIBLING SMOKING AND ITS POSSIBLE EFFECT ON THE SALIVA THIOCYANATE OF NON-SMOKING CHILDREN

Recent studies have suggested that smoking by adults in the home adversely affects the respiratory health of children in their families. ${ }^{11} 12$ This consideration lends some significance to the finding of this study which indicated that where high 
concentrations of saliva thiocyanate were recorded among non-smoking children these children tended to come from smoking as opposed to non-smoking homes. The finding is, however, limited by the lack of statistically significant results and several additional factors. Children from homes in which their parents smoke are more likely to smoke themselves ${ }^{17} 18$ and given that a proportion of the children in this sample may have denied smoking, the higher thiocyanate concentrations may indicate the presence of children who failed to report that they smoked. Other factors outside the scope of this investigation, which may have affected exposure to hydrogen cyanide and consequently the concentrations of thiocyanate detected in children's saliva, might include hours of exposure to sidestream smoke, cigarette consumption by parents, travelling in the smoking section of public transport, and so on. Rates of detoxification of the irritant would also probably vary among individuals. Nevertheless, the trends shown by this study do suggest possible avenues for future detailed investigation regarding the physical effects of passive smoking.

We would like to thank the Health Education Council for supporting this research.

Requests for reprints to Pam Gillies, Department of Community Health, University Hospital and Medical School, Clifton Boulevard, Nottingham.

\section{References}

${ }^{1}$ Evans RI, Hansen WB, Mittlemark MB. Increasing the validity of self-reports of behaviour in a smoking in children investigation.J Appl Psychol 1977; 62: 521-3.

${ }^{2}$ Evans RI, Henderson AH, Hill PC, Raines BE. Current psychological, social and educational programs in control and prevention of smoking: a critical methodological review, Atherosclerosis Review 1979; 6: 203-43.
${ }^{3}$ Maliszewski TF, Bass DE. True and apparent thiocyanate in body fluids of smokers and non-smokers. J Appl Physiol 1955; 8: 289-91.

${ }^{4}$ Courant $P$. The effect of smoking on the antilactobacillus system in saliva. Odoniologisk Revy 1967; 18: 251-61.

${ }^{5}$ Densen PH, Davidow B, Bass HE, Jones EN. A chemical test for smoking exposure. Arch Environ Health 1967; 14: 865-74.

${ }^{6}$ Barylko-Pikielna N, Pangborn RM. Effect of cigarette smoking on urinary and salivary thiocyanate. Arch Environ Health 1968; 17: 739-45.

${ }^{7}$ Dacre CJ, Tabershaw PR. Thiocyanate in saliva and sputum. Arch Environ Health 1979; 21: 47-9.

${ }^{8}$ Tenovuo J, Mäkinen KK. Concentration of ionizable iodine in saliva of smokers and non-smokers. J Dent Res 1976; 55: 661-3.

${ }^{9}$ Hurd PD, Johnson CA, Pechacek TF, Bast LP, Jacobs DR, Luepker RV. Prevention of smoking in seventh grade students. Journal of Behavioural Medicine 1980; 3: $15-28$.

${ }^{10}$ Luepker RV, Pechacek TF, Murray DM, Johnson CA, HURD PD, Jacobs DR. Saliva thiocyanate: a chemical indication of cigarette smoking in adolescents. Minnesota: Laboratory of Physiological Hygiene, School of Public Health, 1980.

1 Yarnell JWG, St Leger AS. Respiratory illness, maternal smoking habit and lung function in children. $\mathrm{Br} J \mathrm{Dis}$ Chest 1979; 73: 230-6.

${ }^{12}$ Bonham GS, Wilson RW. Children's health in families with cigarette smokers. Am J Public Health 1981; 71: 290-3.

${ }^{13}$ Stock S. The perils of second-hand smoking. New Scientist 1980; 88: 10-3.

${ }^{14}$ Wilcox B, Gillies PA. A longitudinal cohort study on the effect of the "my body" project upon knowledge, attitudes and behaviour in respect of smoking and a study of the prevalence of smoking amongst Sheffield school children and their parents. Report to Sheffield Local Education Authority and the Health Education Council, London, 1981.

${ }^{15}$ Banks MH, Bewley BR, Bland JM, Dean JR, Pollard V. Long-term study of smoking by secondary schoolchildren. Arch Dis Child 1978; 53: 12-9.

${ }^{18}$ Pechacek TF, Luepker RV, Jacobs DR, Fraser GE, Blackburn H. Effect of diet and smoking on serum and saliva thiocyanate. American Heart Association Cardiovascular Epidemiology Newsletter 1979; Spring edition.

${ }^{17}$ O'Rourke A, Wilson-Davies K. Smoking and school children. J R Coll Gen Pract 1970; 20: 354-60.

${ }^{18}$ Bewley BR, Bland JM, Harris R. Factors associated with the starting of cigarette smoking by primary school children. Br J Prev Soc Med 1974; 28: 37-44. 